\title{
Distal radius kırıklarının cerrahi tedavisi
}

\author{
Surgical treatment of distal radius fractures
}

\author{
Kemal Özaksar, Tahir Sadık Sügüun
}

EMOT (El Mikrocerrahi Ortopedi ve Travmatoloji) Hastanesi

\begin{abstract}
Distal radius kırıkları sık görülen yaralanmalardandır. Buna rağmen ideal tedavi yöntemleri konusunda fikir birliği yoktur. Tedavide algoritm oluşturmak için yapılan ileriye dönük kontrollü çalışmalar, objektif bulguların ortaya koyması bakımından halen yetersizdir. Genç ve aktif hastalardaki tatmin edici olmayan sonuçların en sık olası nedeni, eklem yüzünün uyumsuzluğudur. Bunun için, eklem yüzü uyumunun sağlanarak, ağrısız el ve el bileği fonksiyonu elde edilmesi tedavinin ana hedefidir. Son on yılda, stabil olamayan kırıkların tedavisinde kullanılan internal ve eksternal tespit malzemeleri ve cerrahi teknikteki ilerlemeler sonuçların gelişmesini sağlamıştır. Birçok cerrahi tespit yöntemi, eklem yüzünün ve eşlik eden interkarpal patolojilerin tam rekonstrüksiyonunu sağlayarak, kırık tedavisi için erken rehabilitasyon protokollerine izin vermektedir. Bu yazıda, sık kullanılan tespit yöntemlerine göre distal radius kırıklarının cerrahi tedavisi tartışılmıştır.
\end{abstract}

Anahtar sözcükler: distal radius; kırıklar; cerrahi tedavi
Fractures of distal radius are one of the most common injuries. In spite of this, ideal treatment methods remain without common sights. Prospective-controlled trials for management algorithms are still insufficient to lend objective findings. Incongruity of articular surface is the most probable cause of unsatisfactory outcomes in young and active patients. So, the primary goals of treatment should be restoration of articular congruence and pain free hand and wrist function. Over the past decade new developments in internal and external fixation techniques and devices for the treatment of unstable fractures have improved results. Many surgical fixation methods allow accurate reconstruction of joint surface, associated intercarpal pathology, and allow early rehabilitation protocols for fracture treatment. In this manuscript, frequently used surgical treatment methods of distal radius fractures were discussed according to fixation methods.

Key words: distal radius; fractures; operative therapy

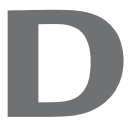
istal radius kırıklarının cerrahi tedavisi için bölgenin anatomik özelliklerinin iyi bilinmesi gereklidir. Radius distal eklem yüzünün ön-arka planda ortalama $22^{\circ}$, yan planda ise $5-11^{\circ}$ arasında değişebilen eğimi bulunmaktadır. Nötral pozisyonda radius stiloidinin radyoulnar eklemden yüksekliği 5-15 mm arasındadır. Radius distal ucunun üç kolon şeklinde tanımlanması, radius distal metafiz kırıklarının patoanatomisinin daha iyi anlaşılmasını sağlamış ve tedavide yol gösterici olmuştur. Kolon konseptine göre, radyal kolon, radyal stiloid ve skafoid fossadan; orta kolon, lunat fossa ile sigmoid çentikten; ulnar kolon ise distal ulna, distal radyoulnar eklem (DRUE) ile triangüler firokartilaj kompleks (TFKK)'den oluşur (Şekil 1). El bileğine gelen yükün büyük kısmı orta kolon tarafindan aktarılır. Radyal kolon, kemik destek görevi görür ve yükün az bir kısmının aktarımında görev alır. Ulnar kolon, stabil dönme noktasıdır, DRUE ile radiusun ulna üzerinde dönmesini sağlar. Özellikle yumruk sıkma esnasında yükün önemli bir bölümü ulnar kolondan aktarılır. ${ }^{[1]}$ Kolon konsepti kompleks kırıkların cerrahi tespitlerinin daha iyi anlaşımasını sağlamış ve kolonların anatomisine özgün implantların gelişmesine katkı sağlamıştır. Radius distal uç kırıklarında, dorsal kenar kırıkları haricindeki kırıklar, el bileği hiperekstansiyonu ile oluşurlar. Lunat ile radius pozisyonuna ve kuvvetin geliş yönüne göre kırık tipleri değişir. Kırık tedavisinin planlanmasında ön-arka ve yan grafiler gerekli çoğu bilgiyi verirken, bilgisayarlı tomografiler (BT) eklem içi kırıklarda daha net bilgiler vermektedir. BT, orta kolon ve önemli eklem parçalarının pozisyonunu göstererek, cerrahi yönünde karar vermede ve yaklaşımımızın belirlenmesinde yardımcı olur. Eğer skafolunat ya da lunotrikuetral bağ gibi interkarpal bağ yaralanmasından şüpheleniliyorsa, manyetik rezonans (MR) inceleme yapılması uygun olur.

- İletişim adresi: Dr. Kemal Özaksar, EMOT (El Mikrocerrahi Ortopedi ve Travmatoloji) Hastanesi, 1418 Sokak No: 14 Kahramanlar, İzmir, Türkiye Tel: 0232 - 4410121,0532 - 5083402 Faks: 0232 - 4411644 e-posta: kemal.ozaksar@hotmail.com

- Geliș tarihi: 25 Șubat $2014 \quad$ Kabul tarihi: 25 Șubat 2014 

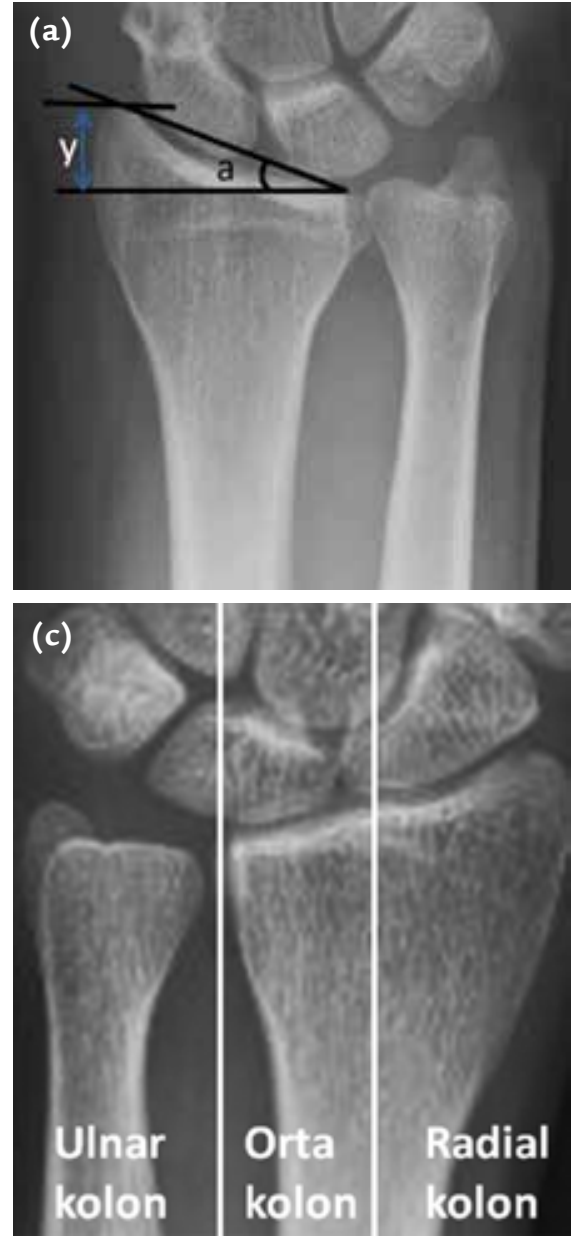

\section{SINIFLAMALAR}

Radius distal uç kırıkları için pek çok sınıflama yapılmıştır. Bunların çoğu bilimsel amaçlarla kullanılmış olup, tedaviye katkıları sınırlıdır. Günümüzde en sık kullanılan AO sınıflaması distal radius kırıklarını üç gruba ayırmaktadır. ${ }^{[2]} \mathrm{A}$ grubu, eğici kuvvetlerle oluşan eklem dışı kırıkları; B grubu, makaslama ya da ezici kuvvetler ile oluşan kısmi eklem içi kırıkları; C grubu ise makaslayıcı ve ezici kuvvetlerin birlikte yüksek enerji ile oluşturduğu kompleks eklem içi kırıkları tanımlamaktadır. Bir diğer sık kullanılan sınıflama Fernandez sınıflamasıdır. ${ }^{[3]}$ Oluş mekanimasına göre kırıkları 5 gruba ayırmaktadır. Tip I kırıklar, metafizdeki bükülme kuvvetleri ile oluşurlar ve eklem dışı kırıklardır. Tip II kırıklar, makaslama kuvvetleri ile oluşurlar; kısmi eklem içi kırıklar şeklindedirler. Tip III kırıklar, eklem yüzündeki ezici kuvvetler ile oluşan eklem içi kırıklardır; metafizer ve subkondral impaksiyon oluşur. Tip IV kırıklarda bağların avulsiyonuna bağlı ulnar, radyal stiloid kırıkları ile birlikte radyokarpal kırıklı çıkık oluşur. Tip V kırıklar, bükücü,

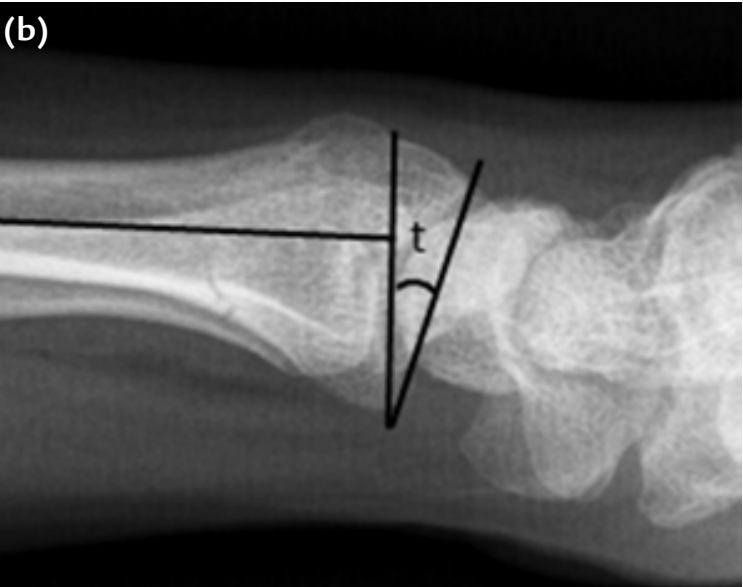

Şekil 1. a-c. Radyolojik parametreler (y, radyal yükseklik; a, radyal eğim; t, palmar eğim) (a, b). Kolon konseptine göre kolonların görünümü (c).

makaslama, ezici ve avulsiyon mekanizmalarının birlikte oluşturduğu, yüksek enerji ile oluşan ve sıklıkla kemik kaybının eşlik ettiği kırıklardır.

\section{TEDAVIDE AMAÇ VE SEÇENEKLER}

Bu kırıklarının cerrahi tedavisindeki amaç, stabil anatomik redüksiyon sağlayarak el ve el bileği fonksiyonlarının en kısa zamanda geri kazanılmasının sağlanmasıdır. Stabil olan eklem dışı kırıklar ya da minimal yer değiştirmesi olan eklem içi kırıklarda, kapalı yerleştirme ve alçılama ile başarılı sonuçlar alınabilmektedir. Ancak eklem içi basamaklanması $2 \mathrm{~mm}$ ve üzerinde, metafizer açılanması $20^{\circ}$ 'den ve metafizer çökmeye bağlı gelişen kısalığı ise $3 \mathrm{~mm}$ 'den fazla, beraberinde ulna kırı̆ı ya da osteoporozu olan kırıklarda, alçılama süresince ikincil yer değiştirme olasılığı yüksektir. ${ }^{[4]} \mathrm{Her}$ ne kadar bu kırıklarda anatomik dizilimin sağlanmasının gerekliliği tartışmalı olsa da, klinik ve biyomekanik çalışmalarda radyal uzunluğun mutlaka sağlanması, palmar tilt ve radyal eğimin kısmen de olsa düzeltilmesi gerekliliği ortaya konmuştur. ${ }^{[5]}$ Tedavi sonrası ağrı, genellikle dorsal açılanmanın $15^{\circ}$ 'den fazla, radyal eğimin $10^{\circ}$ 'den küçük ve radyal uzunluk kaybının 2 mm'nin üzerinde olduğu yanlış kaynamalara eşlik etmektedir. ${ }^{[6]}$ Eklem yüzündeki dorsal açılanma skafoid ve lunat fossadaki yüklenme miktarını, radyal eğimin kaybı ise lunat temas alanındaki yüklenmeyi arttırarak radyokarpal eklemde dejeneratif değişikliklere neden olmaktadır. Eklemde uygun dizilimin sağlanması, eklem hareket açıklığının korunmasını sağlayıp radyokarpal ve distal radyoulnar eklemde artroz ve ağrı gelişme olasılı̆ı̆ıı azaltmaktadır. ${ }^{[7]}$

Radius distal uç kırıklarında cerrahi tedaviye karar verirken göz önünde bulundurulması gereken 
parametreler; hastanın yaşı, aktivite düzeyi, yandaş sorunları, kemik kalitesi, yaralanmanın enerjisi, kırığın radyokarpal ya da radyoulnar ekleme uzanıp uzanmadığı ve metafizer çökmenin derecesi olarak sayılabilir. Genç ya da aktif bireylerde yüksek enerji ile oluşan kırıklarda cerrahi tedavi konusunda fikir birliği varken; özellikle ileri yaş osteoporotik kırıklarda cerrahi tedavi uygulama gerekliliği tartışmalıdır. Son yıllarda bu bölgeye özel anatomik implantların hızlı gelişme göstermesine rağmen, günümüzde kapalı yerleştirme ve perkütan telleme ile eksternal fiksatör tespiti de güncel tedavi yöntemleri içinde sayılmaktadır.

\section{KAPALI REDÜKSIYON PERKUTANÖZ TELLEME}

Bu yöntemin uygun endikasyonu, metafizer parçalanmanın olmadığı eklem dışı ya da basit eklem içi kırıklardır. Perkutan telleme, metafizer parçalanmanın belirgin olduğu, radyal kısalığın eşlik ettiği osteoporotik kırıklarda uygulanmamalıdır. Perkutan telleme ile ilgili literatürde pek çok teknik tanımlanmıştır. Bunlar arasında, radyal stiloidden telleme, radyal ve ulnardan diyafize doğru çapraz telleme, intrafokal telleme ve transulnar telleme sayılabilir. Radyal stiloidden telleme sık kullanılan bir yöntem olup, teller proksimal parçanın ulnar korteksine gönderilir. Kapandji'nin tarif ettiği intrafokal kırık hattından tellemede ise amaç, tellerin yaptığı destek etkisi ile distal parçanın rotasyonunu ve uzunluğunu kontrol etmektir (Şekil 2). Belirgin metafizer parçalanmanın olduğu durumlarda perkütan telleme; kemik grefti, kemik grefti yerini tutan maddeler ya da eksternal fiksatör ile desteklenerek kullanılabilmektedir. ${ }^{[8]}$

Bu tekniğe bağlı gelişebilecek komplikasyonlar arasında; radyal sinir duyu dalı hasarı, telin tendon içerisinden geçmesi, tendon yaralanması, tel migrasyonu, çivi dibi enfeksiyonu sayılabilir. Radyal sinirin duyu dalı ve tendon hasarını engellemek için stiloid üzerinden küçük bir cilt kesisi yapılarak kemiğe kadar künt diseksiyon uygulanıp, koruyucu yardımıyla teller gönderilebilir. Teller genellikle altıncı haftada çekilir. Çivi dibi enfeksiyonları genellikle yüzeyeldir; pansuman ve antibiyotik ile tedavi edilebilirler. Çivi dibi enfeksiyonlarının engellenmesi için teller cilt altında bırakılabilir. Ancak bu yöntemin dezavantajı ikincil bir cerrahi gerekliliğidir.

Yöntemin sonuçları incelendiğinde, Glickel ve arkadaşlarının 55 olgudan oluşan ortalama 5 yıllık takiplerinde, A2-A3-C1-C2 tip kırıkların birinde, tespit yetmezliğine bağlı tekrar ameliyat gerekmiş ve hepsinde mükemmel sonuç elde edilmiş. ${ }^{\left[{ }^{[9}\right.}$ Sthrom ve arkadaşları, A2-A3-C1 tipinde kırığı olan 81 hastada ileriye dönük takip ile radyal stiloid tellemesi ve intrafokal tellemeyi karşılaştırmışlar; hepsinde iyi sonuç bulmakla birlikte, intrafokal tellemenin fonksiyonel ve radyolojik olarak daha iyi olduğunu bulmuşlardır. ${ }^{[10]}$ Trumble ve arkadaşları, eksternal fiksatörle desteklenen intrafokal tellemelerde, desteklenmeyenlere oranla özellikle radiusun çift korteksinin kırıldığı ileri yaştaki hastalarda daha başarılı sonuçlar bildirmişlerdir. ${ }^{[1]]}$

\section{EKSTERNAL TESPIT}

Radius kırıklarında köprüleyen eksternal fiksatörler, ligamentotaksis ile kırık parçalarının redüksiyonunu sağlamak için kullanılır. İnstabil eklem dışı kırıklar; iki ya da üç parçalı, deplasmanı olmayan eklem içi kırıklarda kalıcı tedavide, aşıı yumuşak doku defekti bulunan açık kırıklarda ve politravmalı hastalarda kalıcı yöntem öncesinde geçici olarak uygulanabilirler. Bunun yanında,
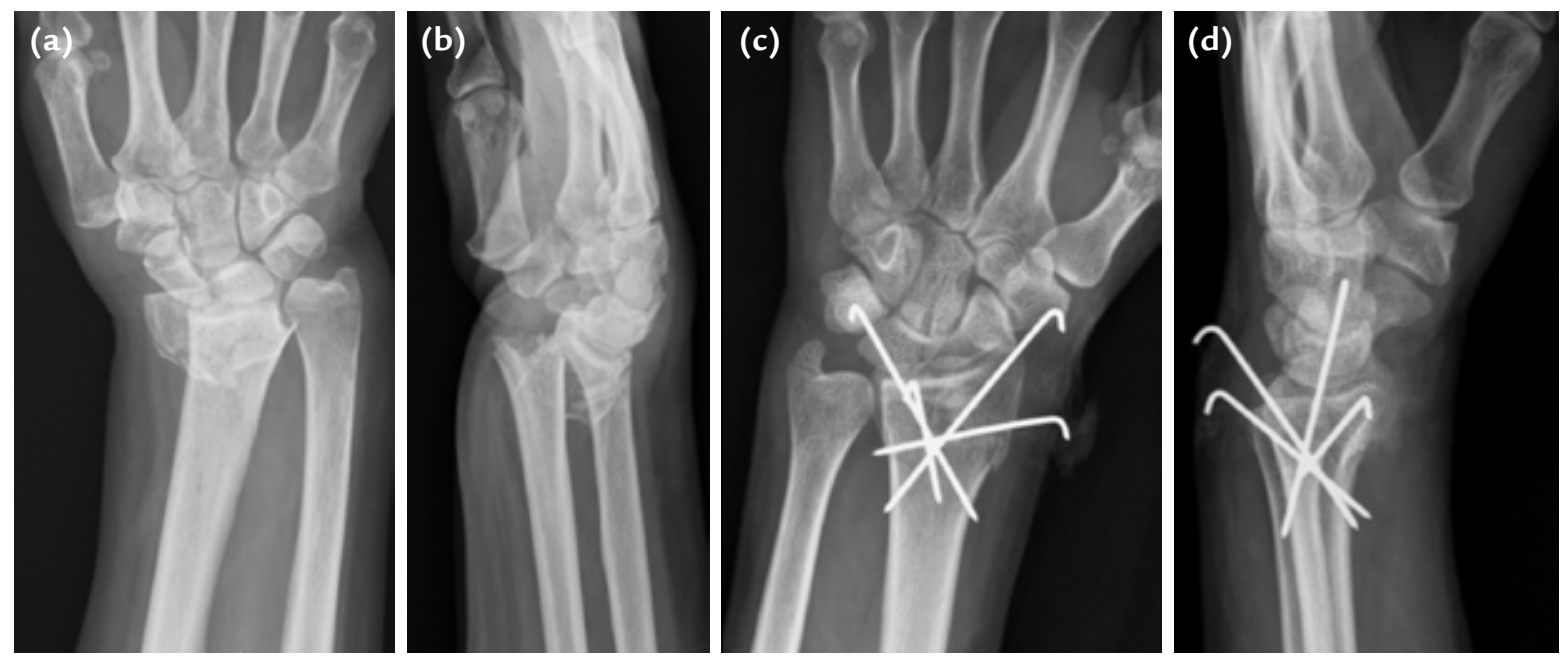

Şekil 2. a-d. Düşme sonrasında oluşan AO tip A3 kırığın ön-arka ve yan grafisi (a, b). Kapalı redüksiyon sonrasında intrafokal ve ekstrafokal çapraz tellemenin uygulandığı tespit yönteminin radyografik görünümü (c, d). 

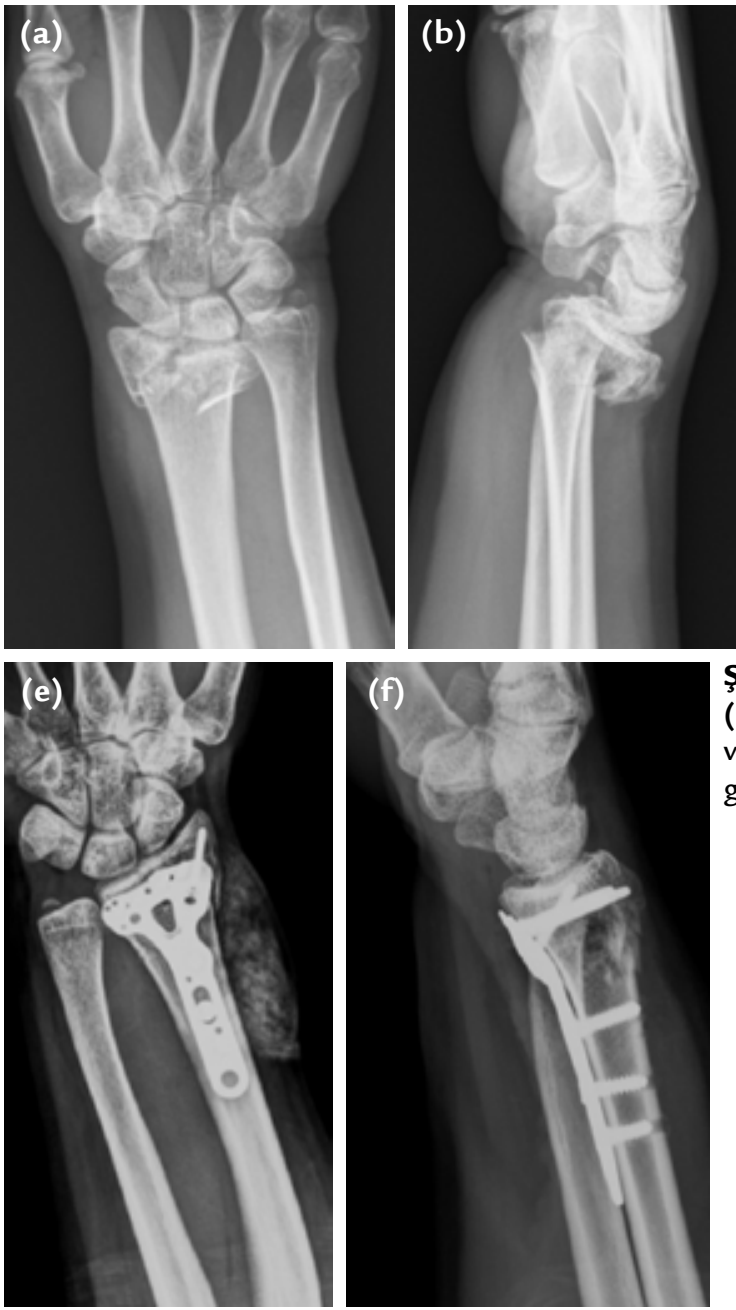

radyal stiloid kırıklarında, üç parçalı eklem içi kırıklarda K-teli tespiti ile birlikte kullanılabilirler. El bileği supinasyonda, düz traksiyon ile volar radyokarpal bağların gerilmesiyle, radyal yükseklikte düzelme sağlanır; fakat palmar eğim açısı tam olarak düzelmez. ${ }^{[12,13]}$ Ayrıca, bu yöntem çökmüş olan lunat fossa bağlarını düzeltmediği gibi, aşııı traksiyon palmar parçanın rotasyonuna neden olabilir. Volar Barton kırıklarında, belirgin metafizer parçalanmada, volar karpal bağların yaralandığı radyokarpal çıkıklarda, instabil distal radyoulnar eklem varlığında kullanılmamalıdır. Kötü sonuçlar, sıklıkla aşııı distraksiyon uygulaması sonrasında görülür. Aşırı distraksiyon, el bileğinde sertliğe, pronasyon kontraktürüne, karpal tünel sendromuna, kompleks bölgesel ağrı sendromuna (KBAS) neden olabilir. ${ }^{[13]}$ Aşııı traksiyonun negatif etkilerinden kaçınmak için el bileğini köprülemeyen eksternal fiksatörler dizayn edilmiştir. Bu fiksatörlerin distal pin'leri distal radyal parçanın içine girererek radyokarpal eklemi köprülemez ve erken harekete izin verir. Parçaların direkt manipülasyonu ile redüksiyon
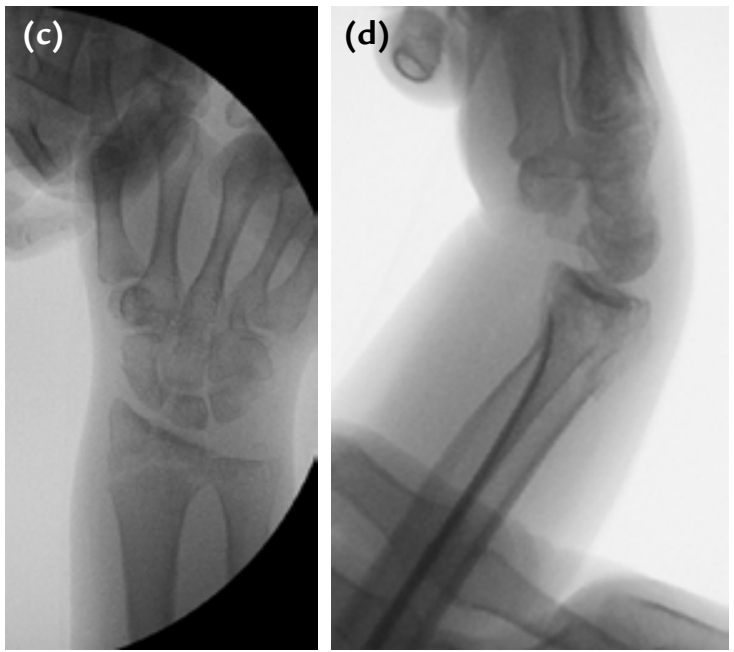

Şekil 3. a-f. Parçalı, eklem içi ön-arka ve yan grafileri (a, b). Skopi altındaki traksiyon görüntüsü (c, d). Kırığın volar anatomik plak ile tespiti sonrasındaki ön-arka ve yan grafileri (e, f)

sağlanabilir. Köprülememe yöntemi ile tespit için, yeterli büyüklükte distal parçaya ihtiyaç vardır. Köprüleyen fiksatörlerle karşılaştırıldıklarında radyal kısalığı ve dorsal açılanmayı daha iyi düzelttiğini bildiren yayınlar olmasına rağmen, radius kırıkları için sık uygulanan bir yöntem haline gelmemiştir. ${ }^{[14]}$

Tek başına distraksiyon ve eksternal tespit, eklem içi parçaların anatomik redüksiyonunu sağlamadığı gibi, sonrasında da metafizer çökmeler görülebilir. Bu nedenle, eksternal tespite ek olarak limitli açık redüksiyon, K-telleri ve kemik grefti ile destekleme redüksiyonu sağlayıp stabiliteyi arttırmaktadır. Kombine teknikler, özellikle parçalı kompleks distal radius kırıkları için kullanılabilir. ${ }^{[8]}$ Bu tip kırıklarda, çökmüş kemik parçaları kaldırılıp kemik grefti ile desteklendiğinde, stabilite yanında kaynama yönünde de avantaj sağlanabilmektedir. ${ }^{[15]}$ Internal ve eksternal tespitlerin karşılaştırıldığı yayınlarda, internal tespit daha iyi palmar tilt ve supinasyon sağlarken, eksternal fiksatör tespitinin daha iyi el bilek fleksiyonu ve kavrama gücü sağladığı görülmüştür. ${ }^{[12,13]}$

\section{AÇIK REDÜKSIYON}

Genel olarak, kırık parçalarının yer değiştirme yönü, kırık tipi, eşlik edebilen yaralanmalar ve implant seçimi cerrahi yaklaşım yönünü belirler. Volar deplasmanlı kırıklara volar yaklaşım uygulanırken, dorsale deplase olmuş kırıklarda dorsal veya volar yaklaşım tercih edilebilir. Traksiyon grafileri, kırık tanımlaması ve değerlendirilmesinde, ayrıca cerrahi yaklaşım yönünün belirlenmesinde önemli yere sahiptir (Şekil 3). Son yıllarda 
geliştirilen ve geniş klinik uygulama alanı bulan sabit ya da değişken açılı kilitli plak teknolojisi ile volar, dorsal, kombine ve parçaya özgü yaklaşımlarla, osteopenik kırıklarda bile başarılı sonuçlar bildirilmektedir.

Randomize kontrollü çalışmaların metaanalizlerinden çıkan sonuç, internal tespitin eksternal tespitlere oranla daha anatomik ve fonksiyonel redüksiyon sağladığıdır. ${ }^{[12,16]}$

\section{Volar yaklaşım ve plak tespiti}

El bileği fleksör kıvrımından proksimale, FCR (flexor carpi radialis) tendonu ve radyal arter arasından uzunlamasına volar Henry yaklaşımı uygulanır. Median sinir, fleksör tendonlar ile birlikte ulnar tarafa alınıp korunur. PQ (Pronator Quadratus) kası radyal ve distalden kaldırılır (Şekil 4). Volar yaklaşımda karpal bağlar ve kapsül korunmalıdır. Karpal tünel gevşetilmesi yapılacak ise, median sinir duyu dalını korumak için ulnar tarafta ikinci bir insizyon tercih edilir. Tespit sonrası $\mathrm{PQ}$ mümkün olduğunca $\mathrm{BR}$ (Brakioradialis) üzerine yaklaştırılır. Genişletilmiş volar yaklaşımda BR kesilip, birinci ekstansör kompartman açılarak radyal stiloid ortaya konabilir. Ayrıca dorsal parça redüksiyonu için kırık hattı proksimali pronasyona getirilerek kırık hattı içinden redüksiyon sağlanabilir. Volar die-punch kırıklarında, volar ulnar taraf parçalı kompleks kırıklarında ve karpal tünel gevşetilmesinin planlandığı durumlarda avuç içine uzanan fleksör kıvrımları oblik olarak geçen orta hat insizyonu kullanılabilir. FCU (flexor carpi ulnaris), ulnar arter ve sinir ulnar tarafa, diğer anatomik yapılar radyal tarafa alınır. PQ radius üzerinden kaldırılıp görüş sağlanır. MIPO tekniği (Minimally Invasive Plate Osteosynthesis) ile cildin ve PQ kasının korunmasıyla volar plaklı tespit mümkün olsa da, klasik yaklaşıma üstünlüğü saptanmamıştır. Eklem içi kırık anatomik redüksiyonu ve uygulama tekniğindeki güçlükler MIPO yönteminin dezavantajlarıdır.[17] Sabit açılı plak uygulamasında distal kısımda vida kullanımı biyomekanik olarak kadavra çalışmalarında peg kullanımına göre üstün bulunmuştur. ${ }^{[18]}$ Distal sırada kullanılacak vida sayısı kullanılan implant ve kırık tipine göre değişim gösterse de, tek sıra vida kullanımı birçok kırıkta redüksiyonu korumak için yeterlidir. ${ }^{[19]}$ Çoğu yazara göre, instabil kırıklarda volar kilitli plak yeterli stabilite, iyi fonksiyonel ve klinik sonuç sağlamaktadır. [20,21] Metafizer parçalanmalı eklem içi kırıkların değişken açılı kilitli plak biyomekanik çalışmalarında, volar uygulamalar dorsal çift plak uygulaması kadar güçlü bulunmuştur. ${ }^{[22]}$ Volar yaklaşım ve plaklı tespit sonrasında el bileği hareketine erken (2. hafta) veya geç (6. hafta) başlamak arasında önemli fonksiyonel fark saptanmamıştır. ${ }^{[23]}$

Dorsal parçalanmış eklem içi kırıkların tespitinde, volar kilitli plaklar biyomekanik olarak K-tellerine üstün bulunsa da; 65 yaş ve üzeri $A 2, A 3$ ve $C 1$ tipi kırıklarda, K-teli tespiti de volar plak tespiti kadar tedavide etkin bulunmuştur. Ancak, erken dönemde serbest hareket gerektiren hastalarda plak tespiti daha avantajlıdır. ${ }^{[24,25]}$ İnstabil eklem dışı kırık tespitinde, sabit açılı intramedüller distal radius çivileri ile karşılaştırıldığında, volar plak tespiti ile arasında uzun dönemde fark bulunamamıştır. ${ }^{[26]}$
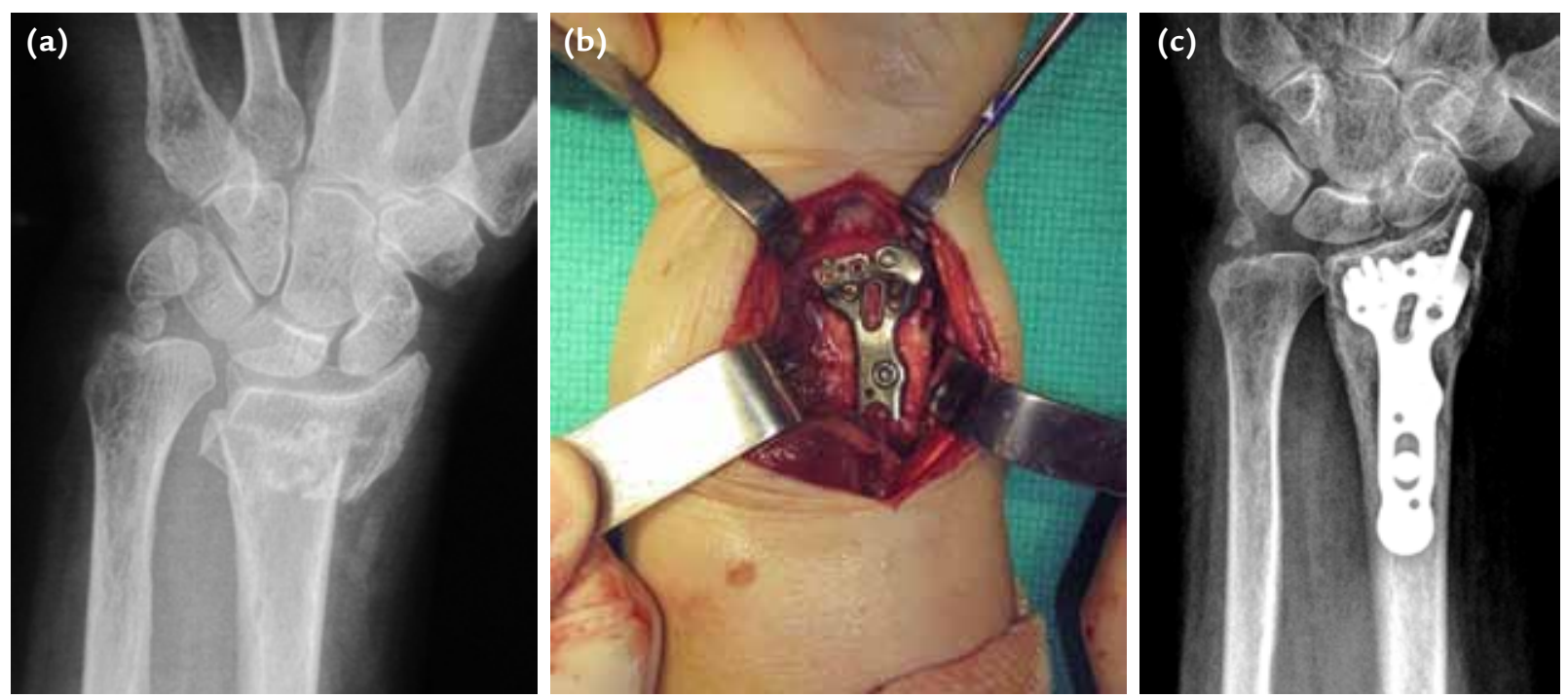

Şekil 4. a-c. Eklem dışı metafizer çökmesi olan radius kırığı (a). Palmar yaklaşım ile plaklı tespit görünümü (b). Ameliyat sonrası X-ray (c). 


\section{Dorsal yaklaşım ve plak tespiti}

Distal radius eklem yüzü üzerinden uzunlamasına, düz ya da kıvrımlı yaklaşık 8-10 cm bir kesi uygulanır. Ekstansör retinakulum, genellikle EPL (extensor pollicis longus) tendonunu serbestleştirecek şekilde, üçüncü kompartman üzerinden açılıp ikinci ve dördüncü kompartmanlar bütün olarak dorsal kemik yüzeyden sıyrılırlar. Dördüncü kompartmanın açılması tercih edilecek olursa, tendonlar ulnar tarafa alınır ve kompartman tabanından posterior interosseöz sinirin terminal dalı rezeke edilebilir. Eklem hattı redüksiyonunun görülmesi gerektiği durumlarda, kapsül radius distal ucu boyunca açılabilir (Şekil 5). Uygulanacak plak tipine göre Lister tüberkülü alınıp dorsal yüz düzeltilebilir. Tespit sonrasında kapsül ve EPL tendonunu cilt altında serbest bırakacak şekilde ekstansör retinakulum onarilır. [27]

Dorsal yaklaşım ve tespit, anatomik redüksiyon için eklem yüzlerinin direkt olarak görülebilmesi ve eşlik eden interkarpal bağ yaralanmasının değerlendirilmesi ve tedavisinde volar yaklaşımdan daha avantajlıdır. Dorsal makaslama (dorsal Barton) kırıkları, dorsal lunat yüz çökme kırıkları ve skafolunat bağ yaralanmasının eşlik ettiği kırıklar dorsal yaklaşımla tedavi edilir. Volar makaslama (volar Barton) kırıkları, volar dudak kırıkları ve volar lunat yüz kırıklarının tespiti dorsal yaklaşım ve tespit ile tedavi edilmeye uygun değildir. Dorsal yüzdeki yumuşak doku inceliği ve ekstansör tendon sorunları bu yaklaşımın en çok bildirilen dezavantajlarıdır. ${ }^{[27]}$
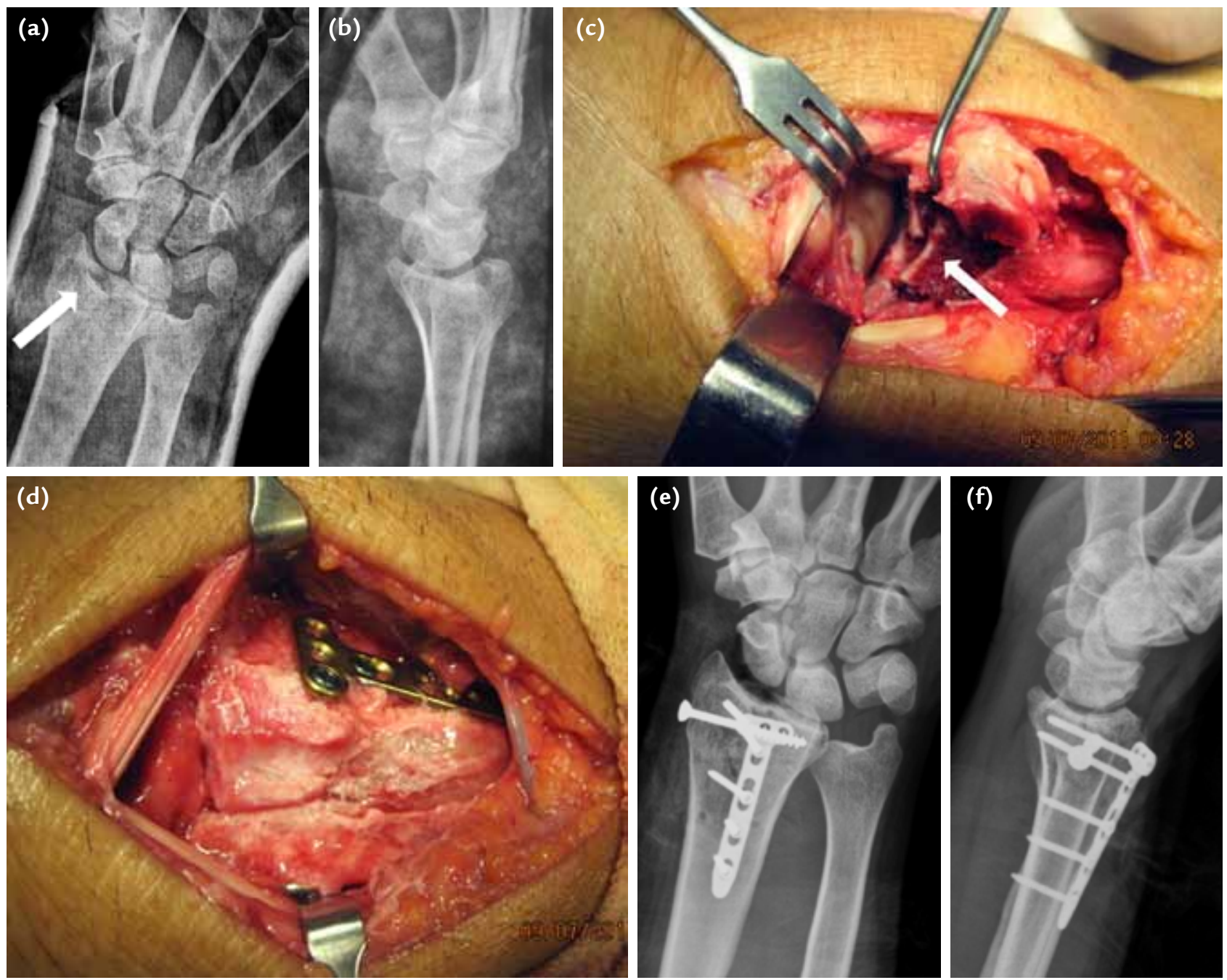

Şekil 5. a-f. Eklem dorsalinde çökme oluşturan (ok) radius distal uç kırık grafileri (a, b). Dorsal yaklaşım ile dorsal radius korteksinin kaldırıldıktan sonra çökmüş eklem parçasının görünümü (c). Deplase dorsal parçanın dorsal destek plağı ile tespitinin görünümü (d). Parça tespiti sonrasındaki radyografi görüntüleri (e, f). 


\section{Limitli açık redüksiyon ve internal tespit}

Kapalı redüksiyon sonrası anatomik redüksiyonu sağlanamayan bazı kırık parçaların yumuşak doku bağlantılarını ve dolaşımlarını bozmayacak şekilde parçanın yerine yönelik yapılan kısıtlı insizyonlardır. Parça tespitleri K-telleri ya da bölge için yapılmış özel implantlar ile yapılabilir. Redükte edilemeyen metafiz kırıkları ve eklem içi kırıklar, eklem yüzlerinin marjinal makaslama kırıkları, radyokarpal kırıklı çıkıklar, kapalı redüksiyon sonrası tekrar yer değiştiren kırıklar, cerrahi tedavi gerektiren karpal ve DRUE yaralanmaları ve yumuşak doku yaralanmasının eşlik ettiği kırıklar limitli açık redüksiyon için uygun değildir.

\section{Kombine yaklaşım ve plak tespiti}

Kompleks eklem içi ve parçalı metafizer kırıklarda, sadece dorsal ya da volar yaklaşım ve tespit yeterli stabilite sağlamayabilir. Palmar parçanın hiperkestansiyona giderek palmar desteğin kaybolduğu, impakte eklem içi kırıklarda, dorsal lunat parçanın çöktüğü kırıklarda ve karpal bağ yaralanmasının olduğu durumlarda, kombine yaklaşım ve tespit uygulanır (Şekil 6). Redüksiyonu sağlamak ve bir arada tutacak şekilde tespit etmek için bu kırıkların tedavisinde hem dorsal hem de volar yaklaşım gerekebilir. Kombine yaklaşım ile parçalı kırıkların tespiti sonrasında, beklenenden daha iyi bir hareket genişliği ve daha az komplikasyon bildirilmiştir. ${ }^{[28]}$

\section{Distraksiyon plaklama}

Çok parçalı, diyafiz uzanımlı kırıklarda dizilimin korunmasına yönelik tanımlanmış bir tespit yöntemidir. Özellikle yaşlı hastaların çok parçalı kırıklarında kullanılır. Radius proksimali ile üçüncü metakarp arasında 3,5 veya $2,7 \mathrm{~mm}$ dinamik kompresyon plağı uygulanır. İmplant çıkartılması için ikincil cerrahi gerekir. Bu yöntemde, $5 \mathrm{~mm}$ ve üzeri radyokarpal eklem distraksiyonundan kaçınılmalıdır. ${ }^{[29]}$

\section{Eklem içi kırıklarda artroskopi kullanımı}

Eklem parçalarının redüksiyonunun görüş altında sağlanması, eşlik eden bağ yaralanmalarının tanı ve tedavisinin yapılabilmesi ve eklem içi kalıntıların uzaklaştırılabilmesi, bu tekniğin avantajlarındandır. Eklem içi kırıkların redüksiyonunda, açık redüksiyona oranla daha az invazivdir. Dorsal yaklaşım yapılmadan, küçük parçaların dolaşımı mümkün olduğunca korunmuş olur. Sıvı sızmasına bağı gelişebilecek komplikasyonlar, kuru uygulamalar ile önlenebilir. Deneyim ve donanım gerektirmesi yanında, radyolojik yöntemlerle sağlanan redüksiyonun kabul edilebilirliği, bu tekniğin çok yaygın kullanılmamasının nedenlerindendir. Fonksiyonel üstünlük ve bağ yaralanmalarının tedavisi günümüzün tartışmalı konularıdır. ${ }^{[30]}$

\section{ULNA STILOID KIRIKLARI}

Cerrahi tedavi edilmiş distal radius kırığına eşlik eden ulna stiloid kırığının tespiti tartışmalıdır. Bazı cerrahlar semptomatik instabilite ve kaynamama nedeniyle tespit önerirken; bazılarına göre tespitin dezavantajları, fonksiyonel sonuçlara etkisizlik, cerrahi sürenin uzaması ve implant rahatsızıklarıdır. DRUE stabilitesinin değerlendirilmesindeki klinik ve radyolojik değişkenler, tespitin etkisini araştırmayı güçleştirmektedir. Instabilitenin eşlik ettiği ulna stiloid taban kırıklarının tespiti önerilmektedir (Şekil 7). ${ }^{[31,32]}$
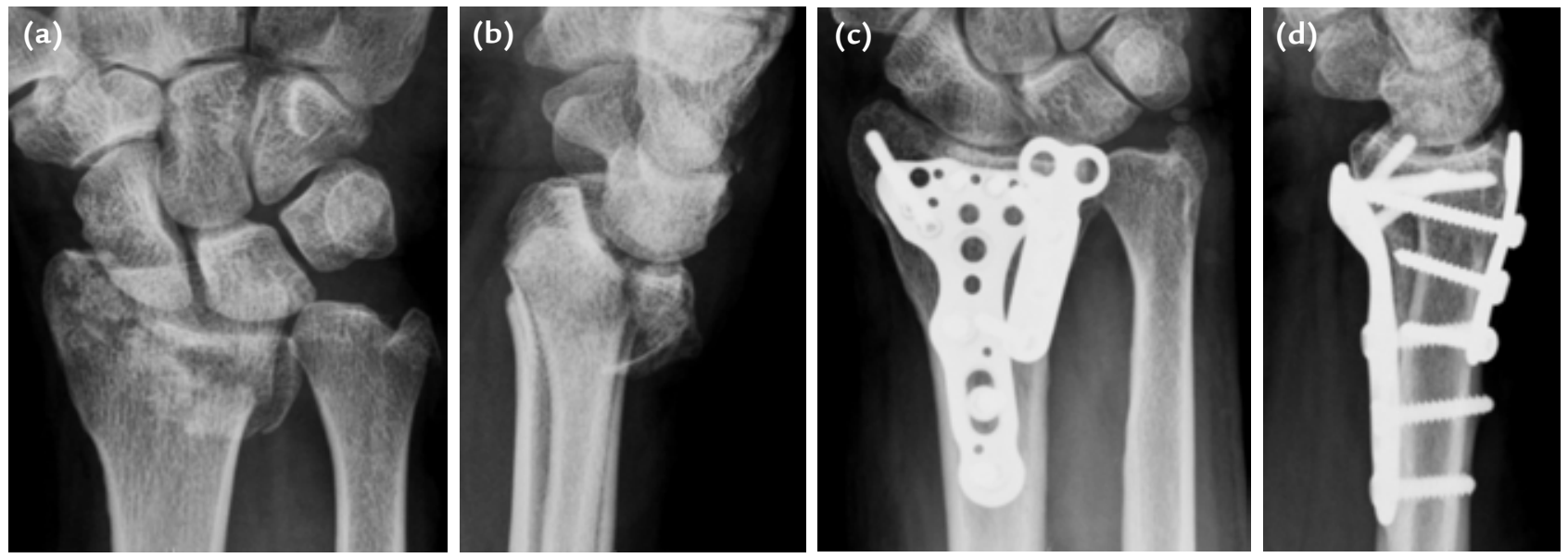

Şekil 6. a-d. Radius distal uç AO tip C2 kırı̆̆ın ön-arka ve yan grafileri (a, b). Dorsoulnar parçanın dorsal destek plağı ile tespitinin yapıldığı dorsal ve palmar kombine plaklama ile anatomik redüksiyonun sağlandığı ameliyat sonrası grafileri (c, d). 

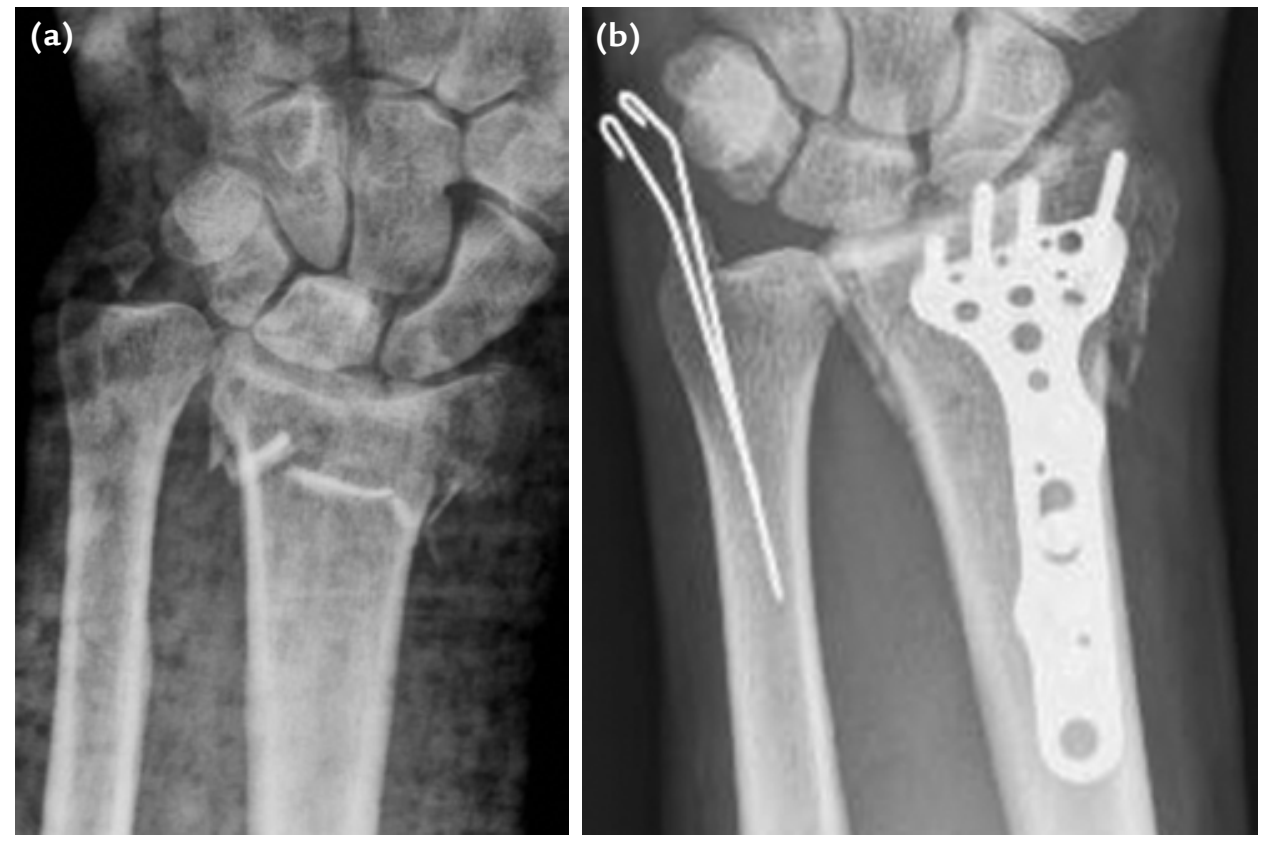

Şekil 7. a, b. Ulna stiloid basis kırığının eşlik ettiği radius distal uç kırığı (a). Stiloid basisinin K-telleri ile, radiusun volar anatomik kilitli plak ile tespiti (b).

\section{KEMIK GREFTLERi VE EŞDEĞERLERi}

Radius distal kırıklarının cerrahi tedavisinde kemik grefti ve eşdeğerlerinin kullanımı, günümüzde bilimsel kanıttan çok uygulama alışkanlıkları ve kişisel deneyimlere dayanmaktadır. Genel yaklaşımda, kemik kalitesi, defekt boyutu ve yeri, uygulanan tespit malzemesi kullanımı etkiler. Eklem restorasyonunun iyi sağlandığı ve volar kortekste temasın olduğu dorsal parçalanmalı kırıklarda kilitli plaklarla yapılan tespitlerde, kemik grefti ve eşdeğerlerine çoğu zaman gerek duyulmamaktadır. Açık kırık sonrası oluşan kemik kayıplarında ve uzatma ve açılandırma gereken yanlış kaynama tedavilerinde ise, biyolojik ve mekanik özellikler, morbidite ve maliyetle birlikte değerlendirilerek uygulanabilir. ${ }^{[15]}$

\section{EŞLIK EDEN YARALANMALAR VE YAKLAŞIM}

Distal radius kırıklarına eşlik eden yaralanmalar, kırık tedavisi ile birlikte değerlendirilmeli ve dikkate alınmalıdır. Bu yaralanmalar, tedavi ve tespit yönteminin belirlenmesiyle birlikte fonksiyonel sonuçlara doğrudan etkilidir.

\section{Açık kırıklar}

Çok sık görülmese de, diğer açık kırıklarda olduğu gibi acil olarak değerlendirilmelidir. Ameliyathane şartlarında debridman, irrigasyon, antibiyoterapiye başlanması ve tetanoz profilaksisi tedavinin temel basamaklarını oluşturur. Yaralanma tipi, zamanı ve yumuşak dokuların durumu, tedavi yöntemini belirler (Şekil 8). Illk basamakta geçici eksternal tespit uygulanabileceği gibi, yeterli temizliğin yapıldığı, uygun yumuşak doku örtüsü olan çoğu hastada, plaklı tespit uygulanabilmektedir. ${ }^{[33]}$

\section{Arter ve sinir yaralanmaları}

Distal dolaşım mutlaka değerlendirilmelidir. Onarım gerektiren arter yaralanmalarının, kapalı kırıklara da eşlik edebileceği unutulmamalıdır. Açık kırıklara ve yüksek enerjili yaralanmalara, cerrahi onarım gerektiren sinir yaralanmaları eşlik edebilir; kırık deplasmanına bağlı median sinir fonksiyon bozukluğuna daha sık rastlanır. Yeterli anatomik dizilimin sağlanması, bu yakınmaların çoğunu düzeltir.

\section{Karpal yaralanmalar}

Kemik yapı, yumuşak doku ya da ikisi birlikte görülebilir. ${ }^{[34]}$ Distal radius kırığının redüksiyonu sonrası karpal yapı değerlendirilmelidir. Özellikle skafoid ve lunat fossa arasına açılan eklem kırıklarına dikkat etmelidir. SL bağ (skafolunat bağ) tam kat yaralanmasında traksiyon grafilerinde skafoidin distale yöneldiği görülebilir. Tedavi yöntemine göre tanıda BT, MR ya da artroskopi uygulanabilir. Dissosiyatif olmayan karpal bağ yaralanmaları immobilizasyon ile iyileşebilirken, dissosiyatif lezyonların tedavisinde, karpal dizilimin tekrar sağlanmasıyla, bağ onarımı ve geçici K-teli tespiti yapılabilir. 

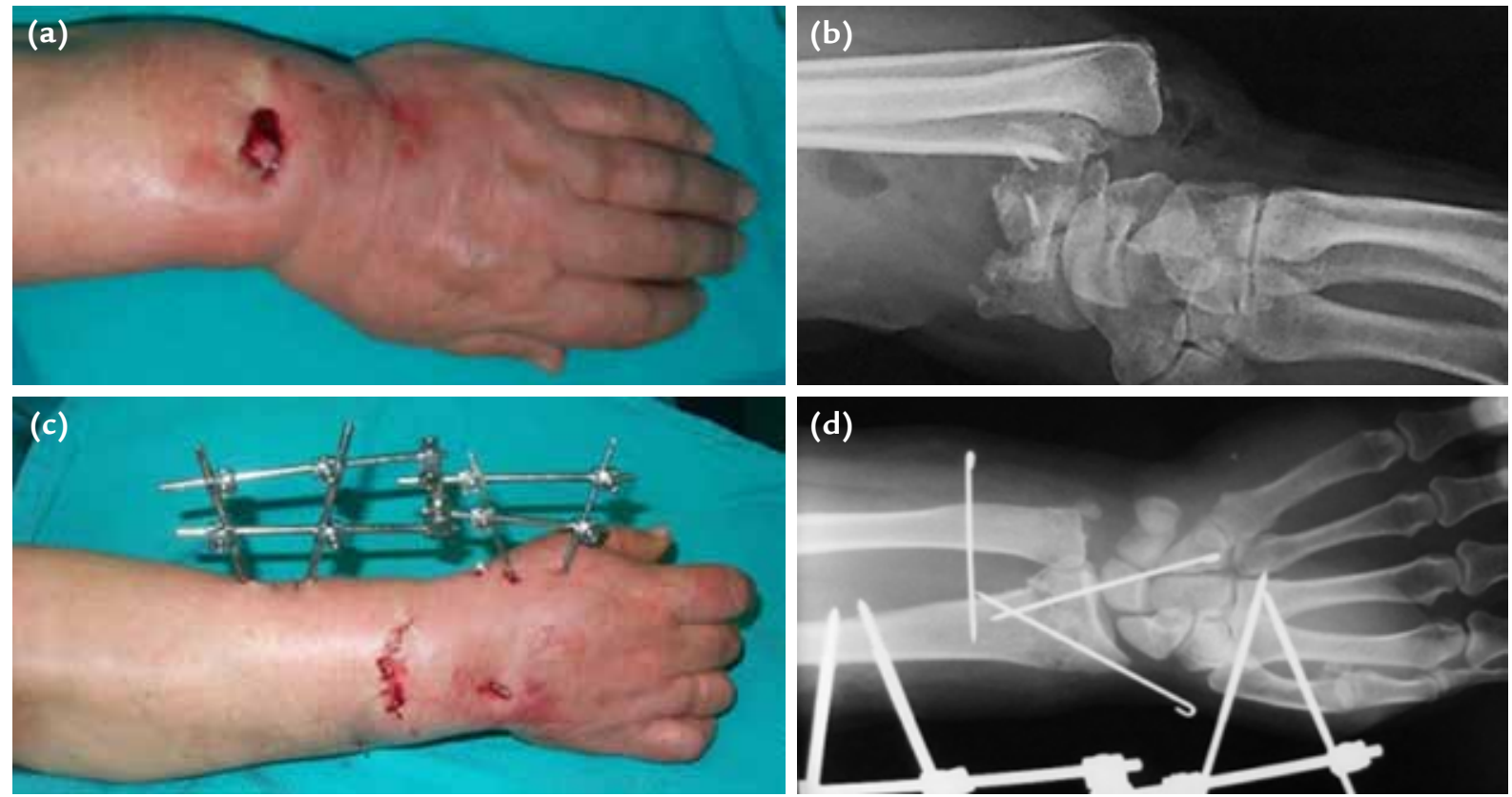

Şekil 8. a-d. Radius distalinde Tip II açık kırığın klinik ve radyografik görünümü (a, b). Eksternal fiksatör ve K-telleri ile tespit uygulaması sonrasında görünüm $(c, d)$.

\section{DRUE yaralanmaları}

DRUE'nin stabilitesi sigmoid çentik - ulna başın redüksiyonuna, TFKK, kapsül ve ulna stiloidinden oluşan kemik ve yumuşak doku kompleks anatomisine bağlıdır. Ön kol, interosseöz membranın distal oblik demeti bölgesinin stabilitesinde önemli yer oynar. ${ }^{[35]}$ Kırık redüksiyonu ile sağlanan sigmoid çentik ve ulna başı redüksiyonu sonrasında, DRUE stabilitesi ayrıca değerlendirilir. El bileği pronasyon-supinasyon hareketleri kontrol edilir. İnstabilite durumunda, yaralanan yapıya göre, ulna baş tespiti, ulna stiloid tespiti, TFKK onarımları uygulanmalıdır. Bu bölgenin ayrıntılı olarak değerlendirilmesi, anatomik, radyolojik ve klinik sonuçları olumlu yönde etkiler.

\section{KOMPLIKASYONLAR}

Tedavide komplikasyonlar, klinik sonuçlar üzerinde çoğu zaman radyolojik sonuçlardan daha etkindir. Eklem sertlikleri, KBAS, median sinir nöropatisi, kaynamama, yanlış kaynama, tendon ve eklem sorunları \%30'a kadar bildirilmiştir. Komplikasyonların en iyi tedavisi, önlemektir; klinik ve radyolojik olarak yakın hasta takibi gerektirir. ${ }^{[36,37]}$

\section{KBAS}

Yaralanma, tedavi ve hasta özelliklerine göre farklı klinik bulgular ile \%8-30 sıklıkta görülebilir. Orantısız yaygın ağrı, vazomotor bulgular, ödem ve ekstremite sertlikleri genel semptomlardır. Klinik bulgu ve yanıta göre tedavi yöntemleri; sıkı sarılmış alçı ya da bandajın gevşetilmesinden, fizik tedavi ile uygulanabilecek medikal tedaviye, sempatik sinir bloklarına kadar değişebilir. ${ }^{[36]}$

\section{Kaynamama}

Nadir görülür $(\% 0,2)$. Genel olarak kemik metabolizmasını etkileyen eşlik eden hastalıklar, sigara ve alkol kullanımı ya da hatalı uygulanan cerrahi teknik sonrası görülür. Distal parça büyüklüğü, kaynamama biyolojisi ve mekaniğine göre tedavi yöntemi belirlenir.

\section{Yanlış kaynama}

Eklem içi basamaklanma, eklem dışı kısalık, rotasyon ve angulasyon şeklinde görülebilir. Anatomik olarak tespit edilmemiş her distal radius kırığında fonksiyonel sonuçlar kötü olmasa da; çoğu hasta azalmış el bilek hareketi, rotasyon kısıtlılığı, kalıcı ulnar taraf ağrısı, güçsüzlük, karpal tünel sendromu (KTS) ve kozmetik bozukluktan şikayet etmektedir. Semptomatik yanlış kaynamamalarda tedavi planlanırken anatomik bozukluğun özelliği, fonksiyonel beklenti, yakınma ve hasta özellikleri değerlendirilmelidir. ${ }^{[38]}$

\section{KTS}

Median sinire ait semptomların başlama zamanı, kırık deplasmanı ve redüksiyonu ile ilgisi ve takip 
tedavi yöntemini belirler. Kırık öncesi yakınması olan hastalarda semptomlar artış gösterebilir, çoğunda redüksiyon ile birlikte kısa dönemde düzelme görülür. Yaralanmaya bağlı sinir kontüzyonunda ise yakınmalar daha uzun sürer. Akut gelişen ve giderek artan semptomlar, karpal tüneldeki basınç artışı ile birlikte kompartman sendromunu düşündürmeli ve tedavi yaklaşımında geç kalınmamalıdır. ${ }^{[36]}$

\section{Enfeksiyon}

Çok kirli olmayan açık kırıklar ve elektif cerrahi tespitleri sonrasında ender görülür. Genel olarak, yüzeyel enfeksiyonlar oral antibiyotik tedavisine iyi yanıt verir. ileri enfekte hastalarda, yumuşak doku debridmanı sonrasında tespit malzemelerinin çıkartılması, yeni tespit yöntemleri ve yumuşak doku kapama yöntemleri uygulanabilir. ${ }^{[36]}$

\section{Tendon yaralanması}

Kırık parçaların etkisi, dorsal plak uygulaması, volar plak uygulaması ve bu uygulamalardaki vida çıkımı ile birlikte EPL, FPL (flexor pollicis longus) rüptürleri, semptomatik ve asemtomatik tenosinovit bulguları tendon yaralanmaları şeklinde bildirilmiştir. Dorsal vida çıkımları, dorsal horizontal grafiler ve ultrasonografi (US) ile tanımlanabilir (Şekil 9). Gerekli görüldüğünde implant çıkartılması uygulanmalıdır. ${ }^{[39,40]}$
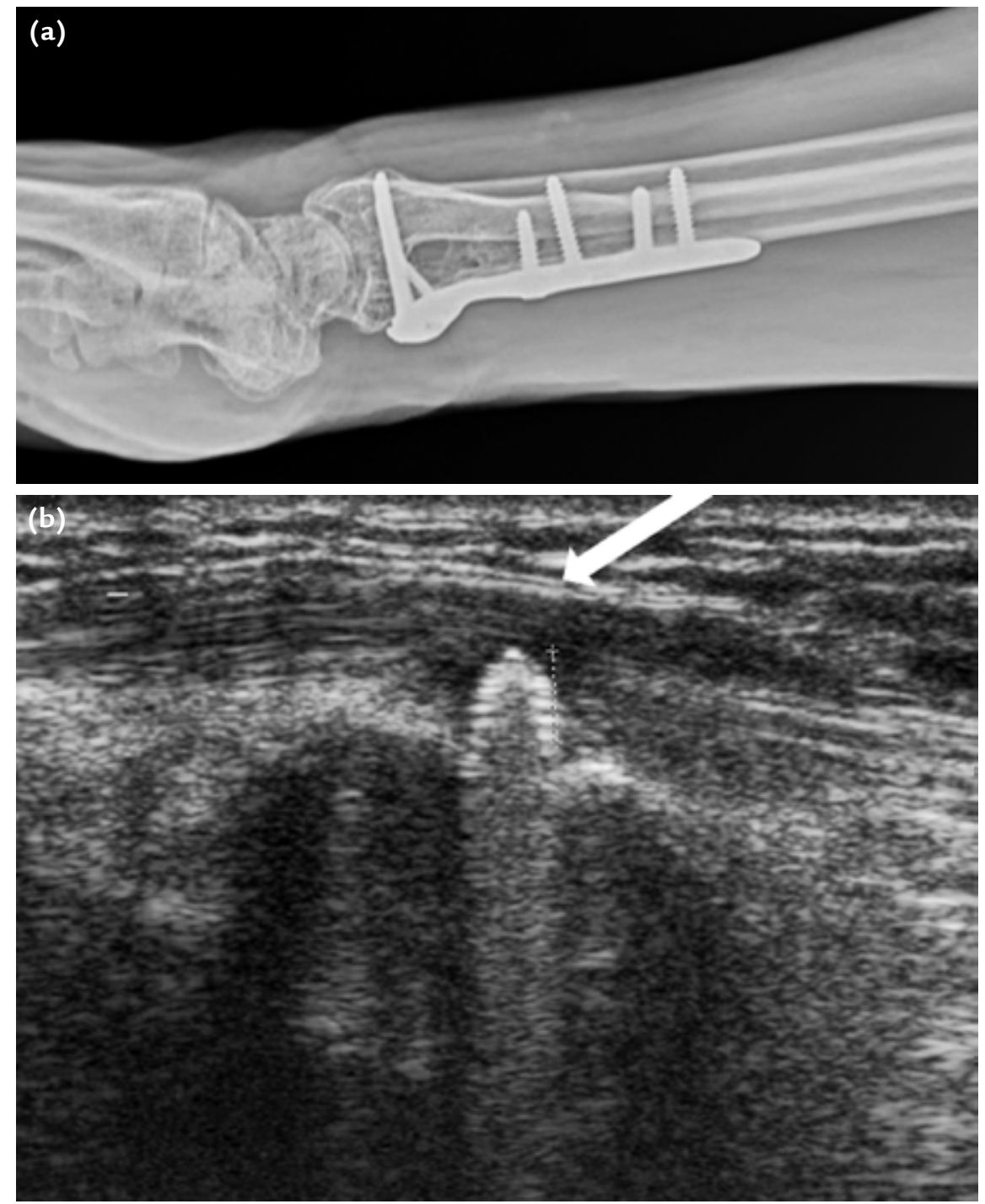

Şekil 9. a, b. Plakla tespit edilmiş radius kırığının lateralden görünümü (a). Dördüncü dorsal kanaldan çıkan ve ekstansör tenosinovite neden olan vidanın US görünümü (ok, b). 


\section{OSTEOPENIKK VE YAŞLI HASTALARDA AÇIK REDÜKSIYON}

Literatürde değerlendirilen yaş grupları farklı olsa da, çoğu 65 yaş ve üzeri hastalarda yapılan çalışmalarda, alçılı tespit dahil tüm tedavi yöntemlerinde başarılı sonuçlar bildirilmiştir. ${ }^{[41]}$ Bazı yazarlara göre, yaştan bağımsız olarak distal radius kırıklarında anatomik redüksiyon sağlanmalı ve tespit edilmelidir, bunun için osteopenik ve osteoporotik kemiklerde en uygun tespit yöntemi kilitli plaklardır. ${ }^{[42]}$ Aksi görüş olarak, bu yaş grubunda çoğu hastada redüksiyon dahi yapılmadan günlük ihtiyaçları karşılayacak bir iyileşme mümkün olmaktadır. ${ }^{[41]}$ Burada önemli olan hastanın beklentileri ve kırığının özelliklerine göre uygun tedavi yöntemini planlamaktır. Osteoporozun fonksiyonel sonuçlar üzerinde olumsuz etkileri dikkate alınmalıdır. ${ }^{[43]}$

\section{SONUÇ}

Yazarlar, kilitli plakların gelişimi ile greft ihtiyacını oldukça azaltması, stabil tespit sağlaması ve erken hareket başlanabilmesi nedeniyle, son yıllarda plakla tespiti diğer yöntemlere göre daha çok tercih etmektedir. Eklem içi kırıklarda, skopi altındaki traksiyon grafileri ile dorsoulnar parçanın redükte olmadığı durumda, lunat fossada eklem içi çökmenin varlığında ve dorsal makaslama kırıklarında dorsal yaklaşımı tercih etmektedirler. Palmar korteks bütünlügünün bozulduğu kırıklarda, palmar yaklaşımı uygulamaktadırlar. Palmar korteks bütünlüğünün bozulduğu ve dorsal yaklaşım endikasyonu olan kırıklarda ise, hem palmar hem dorsal kombine yaklaşımı tercih etmektedirler.

Günümüzde distal radius kırıklarının cerrahi tedavisinde en iyi yöntem ve en iyi tespit malzemesi gibi bir seçim söz konusu değildir. Kırık tipi ve hasta özellikleri, uygulanacak cerrahi tedavi ve tespit yöntemi seçimini belirler. Eşlik edebilecek yaralanmalar ve komplikasyonların dikkatle değerlendirilmesi tedavi sonuçlarını etkiler. Tedavide amaç, uzun dönemde ortaya çıkabilecek kısıtlamaları engelleyecek şekilde el ve bilek fonksiyonlarının kazanımıdır.

\section{KAYNAKLAR}

1. Jakob M, Rikli DA, Regazzoni P. Fractures of the distal radius treated by internal fixation and early function. A prospective study of 73 consecutive patients. J Bone Joint Surg $\mathrm{Br}$ 2000;82(3):340-4.

2. Jupiter JB, Lipton $\mathrm{H}$. The operative treatment of intraarticular fractures of the distal radius. Clin Orthop Relat Res 1993;(292):48-61.

3. Fernandez DL, Geissler WB. Treatment of displaced articular fractures of the radius. J Hand Surg Am 1991;16(3):375-84.
4. Hove LM, Solheim E, Skjeie R, Sörensen FK. Prediction of secondary displacement in Colles' fracture. J Hand Surg $\mathrm{Br}$ 1994;19(6):731-6.

5. Trumble TE, Schmitt SR, Vedder NB. Factors affecting functional outcome of displaced intra-articular distal radius fractures. J Hand Surg Am 1994;19(2):325-40.

6. Buijze GA, Prommersberger KJ, Gonzalez Del Pino J, Fernandez DL, Jupiter JB. Corrective osteotomy for combined intra and extra-articular distal radius malunion. J Hand Surg Am 2012;37(10):2041-9. CrossRef

7. Knirk JL, Jupiter JB. Intra-articular fractures of the distal end of the radius in young adults. J Bone Joint Surg Am 1986;68(5):647-59.

8. Handoll HH, Vaghela MV, Madhok R. Percutaneous pinning for treating distal radius fractures in adults. Cochrane Database Syst Rev 2007;18(3):CD006080.

9. Glickel SZ, Catalano LW, Raia FJ, Barron OA, Grabow R, Chia B. Long-term outcomes of reduction and percutaneous pinning fort the treatment of distal radius fractures. J Hand Surg Am 2008;33(10):1700-5. CrossRef

10. Strohm PC, Müller CA, Boll T, Pfister U. Two procedures for Kirshner wire osteosynthesis of distal radius fractures. A randomized trial.J Bone Joint Surg Am 2004;86-A(12):2621-8.

11. Trumble TE, Wagner W, Hanel DP, Vedder NB, Gilbert M. Intrafocal (Kapandji) pinning of radius distal fractures with and without external fixation. J Hand Surg Am 1998;23(3):381-94.

12. Xie X, Xie X, Qin H, Shen L, Zhang C. Comparison of internal and external fixation of distal radius fractures. Acta Orthop 2013;84(3):286-91. CrossRef

13. Esposito J, Schemitsch EH, Saccone M, Sternheim A, Kuzyk $P R$. External fixation versus open reduction with plate fixation for distal radius fractures: a meta-analysis of randomised controlled trials. Injury 2013;44(4):409-16. CrossRef

14. Capo JT, Swan KG Jr, Tan V. External fixation techniques for distal radius fractures. Clin Orthop Relat Res 2006;445:30-41.

15. Tosti R, llyas AM. The role of bone grafting in distal radius fractures. J Hand Surg Am 2010;35(12):2082-4. CrossRef

16. Wei DH, Poolman RW, Bhandari M, Wolfe VM, Rosenwasser MP. External fixation versus internal fixation for unstable distal radius fractures: a systematic review and metaanalysis of comparative clinical trials. J Orthop Trauma 2012;26(7):386-94. CrossRef

17. Zenke $Y$, Sakai A, Oshige T, Moritani S, Fuse Y, Maehara T, Nakamura T. Clinical results of volar locking plate for distal radius fractures: conventional versus minimally invasive plate osteosynthesis. J Orthop Trauma 2011;25(7):425-31. CrossRef

18. Mehling I, Klitscher D, Mehling AP, Nowak TE, Sternstein W, Rommens PM, Müller LP. Volar fixed-angle plating of distal radius fractures: screws versus pegs--a biomechanical study in a cadaveric model. J Orthop Trauma 2012;26(7):395-401. CrossRef

19. Neuhaus V, Badri O, Ferree S, Bot AG, Ring DC, Mudgal CS. Radiographic alignment of unstable distal radius fractures fixed with 1 or 2 rows of screws in volar locking plates. J Hand Surg Am 2013;38(2):297-301. CrossRef

20. Sügün TS, Gürbüz Y, Ozaksar K, Toros T, Kayalar M, Bal E. Results of volar locking plating for unstable distal radius fractures. Acta Orthop Traumatol Turc 2012;46(1):22-5.

21. Orbay JL, Touhami A. Current concepts in volar fixed-angle fixation of unstable distal radius fractures. Clin Orthop Relat Res 2006;445:58-67. 
22. Rausch S, Schlonski O, Klos K, Gras F, Gueorguiev B, Hofmann $\mathrm{GO}$, Mückley T. Volar versus dorsal latest-generation variableangle locking plates for the fixation of $\mathrm{AO}$ type $23 \mathrm{C} 2.1$ distal radius fractures: a biomechanical study in cadavers. Injury 2013;44(4):523-6. CrossRef

23. Lozano-Calderón SA, Souer S, Mudgal C, Jupiter JB, Ring D. Wrist mobilization following volar plate fixation of fractures of the distal part of the radius. J Bone Joint Surg Am 2008;90(6):1297-304. CrossRef

24. Goehre F, Otto W, Schwan S, Mendel T, Vergroesen PP, Lindemann-Sperfeld L. Comparison of palmar fixed-angle plate fixation with $\mathrm{K}$-wire fixation of distal radius fractures (AO A2, A3, C1) in elderly patients. J Hand Surg Eur Vol 2014;39(3):249-57. CrossRef

25. Knox J, Ambrose H, McCallister W, Trumble T. Percutaneous pins versus volar plates for unstable distal radius fractures: a biomechanic study using a cadaver model. J Hand Surg Am 2007;32(6):813-7.

26. Safi A, Hart R, Těknědžjan B, Kozák T. Treatment of extraarticular and simple articular distal radial fractures with intramedullary nail versus volar locking plate. J Hand Surg Eur Vol 2013;38(7):774-9. CrossRef

27. Lutsky K, Boyer M, Goldfarb C. Dorsal locked plate fixation of distal radius fractures. J Hand Surg Am 2013;38(7):141422. CrossRef

28. Ring D, Prommersberger K, Jupiter JB. Combined dorsal and volar plate fixation of complex fractures of the distal part of the radius. J Bone Joint Surg Am 2005;87 Suppl 1(Pt 2):195-212.

29. Ginn TA, Ruch DS, Yang CC, Hanel DP. Use of a distraction plate for distal radial fractures with metaphyseal and diaphyseal comminution. Surgical technique. J Bone Joint Surg Am 2006;88 Suppl 1 Pt 1:29-36.

30. Herzberg G. J Intra-articular fracture of the distal radius: arthroscopic-assisted reduction. J Hand Surg Am 2010;35(9):1517-9. CrossRef

31. Krämer S, Meyer H, O'Loughlin PF, Vaske B, Krettek C, Gaulke $R$. The incidence of ulnocarpal complaints after distal radial fracture in relation to the fracture of the ulnar styloid. J Hand Surg Eur Vol 2013;38(7):710-7. CrossRef
32. Kim JK, Koh YD, Do NH. Should an ulnar styloid fracture be fixed following volar plate fixation of a distal radial fracture? J Bone Joint Surg Am 2010;92(1):1-6. CrossRef

33. Jawa A. Open fractures of the distal radius. J Hand Surg Am 2010;35(8):1348-50. CrossRef

34. Heo YM, Kim SB, Yi JW, Lee JB, Park CY, Yoon JY, Kim DH. Evaluation of associated carpal bone fractures in distal radial fractures. Clin Orthop Surg 2013;5(2):98-104. CrossRef

35. Moritomo $\mathrm{H}$. The distal interosseous membrane: current concepts in wrist anatomy and biomechanics. J Hand Surg Am 2012;37(7):1501-7. CrossRef

36. Meyer C, Chang J, Stern P, Osterman AL, Abzug JM. Complications of distal radial and scaphoid fracture treatment. J Bone Joint Surg Am 2013;95(16):1517-26. CrossRef

37. Toros T, Sügün TS, Ozaksar K. Complications of distal radius locking plates. Injury 2013 Jan 18. pii: S00201383(13)00020-X. CrossRef

38. Jupiter JB, Fernandez DL. Complications following distal radial fractures. Instr Course Lect 2002;51:203-19.

39. Sügün TS, Karabay N, Gürbüz Y, Ozaksar K, Toros T, Kayalar M. Screw prominences related to palmar locking plating of distal radius. J Hand Surg Eur Vol 2011;36(4):320-4. CrossRef

40. Haug LC, Glodny B, Deml C, Lutz M, Attal R. A new radiological method to detect dorsally penetrating screws when using volar locking plates in distal radial fractures. The dorsal horizon view. Bone Joint J 2013;95-B(8):1101-5. CrossRef

41. Diaz-Garcia RJ, Oda T, Shauver MJ, Chung KC. A systematic review of outcomes and complications of treating unstable distal radius fractures in the elderly. J Hand Surg Am 2011;36(5):824-35. CrossRef

42. Orbay JL, Fernandez DL. Volar fixed-angle plate fixation for unstable distal radius fractures in the elderly patient. J Hand Surg Am 2004;29(1):96-102.

43. Fitzpatrick SK, Casemyr NE, Zurakowski D, Day CS, Rozental TD. The effect of osteoporosis on outcomes of operatively treated distal radius fractures. J Hand Surg Am 2012;37(10):2027-34. CrossRef 